\title{
Fuzzy applications in selected aircraft on-board system
}

\author{
Norbert Grzesik $^{a}$ and Janusz Ćwiklak ${ }^{b}$ Mariusz Zieja $^{c}$ and Grzegorz Kozłowski ${ }^{d}$ \\ aDepartment of Tactics and Armament, Faculty of Aviation, Polish Air Force University, Dywizjonu 303 Street \\ Nu. 35, 08-530 Dęblin, Poland, n.grzesik@law.mil.pl \\ ${ }^{b}$ Department of Navigation, Faculty of Aviation, Polish Air Force University, Dywizjonu 303 Street Nu. 35, 08 - \\ 530 Dęblin, Poland, j.cwiklak@law.mil.pl \\ ${ }^{\mathrm{c} A i r}$ Force Institute of Technology, Księcia Bolesława Street Nu. 6 \\ 01-494 Warszawa, post box nu.96, mariusz.zieja@itwl.pl \\ ${ }^{\mathrm{d}}$ Air Force Base, Brygady Pościgowej Street Nu. 5 \\ 08-521 Dęblin, Poland, grzegorzkozlowski13@wp.pl
}

\begin{abstract}
The authors in this publication present a new approach to aircraft systems efficiency evaluation. The research station consists of two units: an efficiency evaluation unit and a flight simulation unit. The efficiency is evaluated with the use of fuzzy inference systems, designed in Matlab/Simulink Software. The simulations were performed in the X-Plane aircraft simulations software by experienced military pilots and young military and civilian pilots cadets at the Polish Air Force University. The selected results and conclusions end the article.
\end{abstract}

Keywords: Fuzzy inference systems, aircraft systems, efficiency evaluation.

\section{Introduction}

For ages people have been trying to create more perfect and more efficient tools which can be able to replace them in numerous aspects of human life. $[5,9,19,22]$ In 21 -st century implementations became so advanced that constructors were trying to find the best way to create machines which are more and more reliable and have an ability to adjust its behaviour in the constantly changing environmental conditions. One of the way is the use of fuzzy logic. $[2,4,6 \div 8,28,29]$ We can observe an increasing use of fuzzy logic systems in the commercial use of machines in many industrial branches. $[1,17,20,21,23,25 \div 27,30 \div 37]$ Also the authors have some achievements in this area. $[3,14,18,24]$ That is why, the authors proposed to use a designed laboratory station to evaluate selected aircraft onboard system efficiency. The selected system is a gun system. The obtained results were compared to the data received from a fulfilled air task on selected aircraft and its simulator. Mathworks Matlab software was chosen as a tool $[15,16]$ and it was combined with Laminar Research X-Plane software in one aircraft air task efficiency evaluation system (Fig. 1). The main objective of the work is to design fuzzy evaluation system which can increase aircraft efficiency during different air task (in this particular example - increase a gun system efficiency) and supports pilots during air tasks (pilots' decision making support system). The approaching to the problem is original. What is more laboratory station is upgradeable and allows young scientists to understand the idea of fuzzy logic use in aircraft onboard systems, but also of physical phenomena like aircraft lift force (it is supported by many functions available in X-plane software, Fig. 2, 3). MiG-29 aircraft model was used during system work simulations (comes from webpage:

http://xplanefreeware.net/barry/index\%20MiG29.htm 1). The article consists of three main parts. First is description of fuzzy logic evaluator designing process. Second is research results. Conclusion ends the publication.

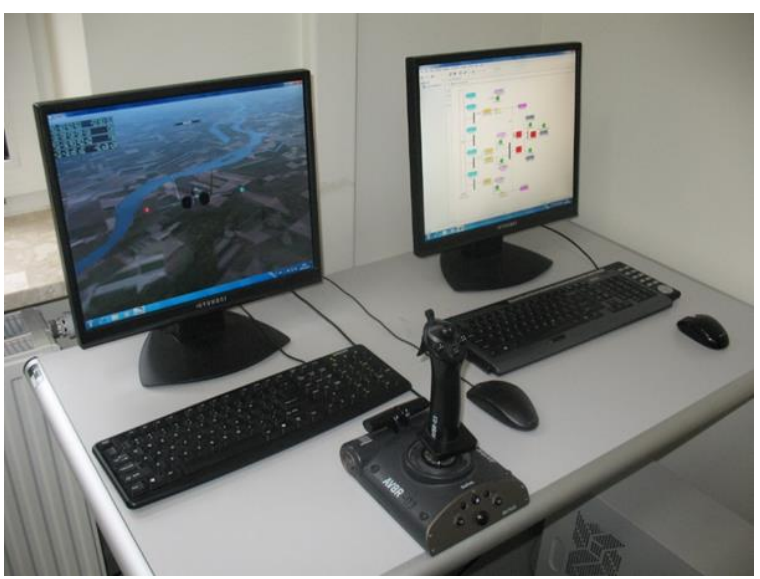

Figure 1: Designed laboratory station. 


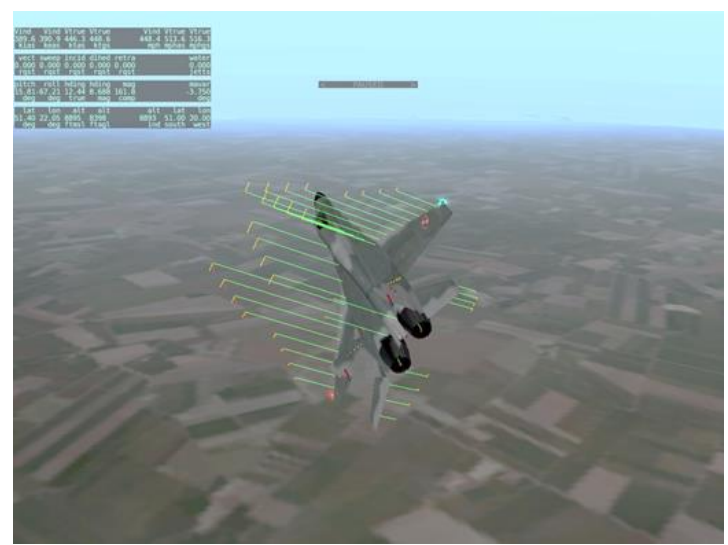

Figure 2: Example of screen from X-plane software (lifting force)

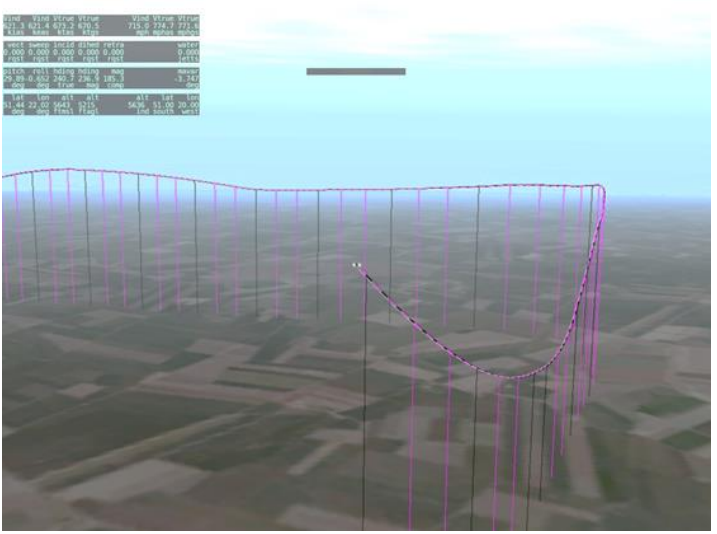

Figure 3: Example of screen from X-plane software (air task trajectory).

\section{Project of a fuzzy evaluator}

\section{A. Project in Matlab/Fuzzy Logic Toolbox}

The first designed in Fuzzy Logic Toolbox fuzzy inference system (fuzzy air task efficiency evaluator) is presented in Fig. 4 and called "predkoscwysoskosc" (in polish language) "velocityaltitude" (in English language). The system is no adaptive Mamdani - Zadeh MISO fuzzy system (Many Inputs, Single Outputs). There are two input signals: aircraft velocity and aircraft altitude, and one output signal: efficiency number 1 . The ranges and parameters of membership functions and also fuzzy rules were determined from aircraft pilots experience and technical documentation as a knowledge base. There are precise air task data (aircraft velocity, altitude, angles) in the aircraft technical documentation, which support recommended efficiency. [10 13] Pilots (with at list 500 flight hours) were selected as experts. They checked all necessary air task data and determined complete rules base. What is more some air task were performed on aircraft simulator and during real mission. The evaluation results depend on input parameters of the system.

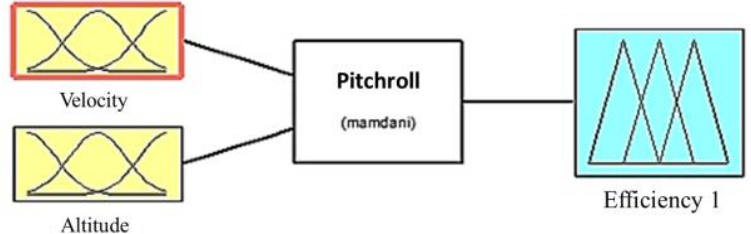

Figure 4: Fuzzy logic evaluator number 1 (Efficiency $1)$.

The second, designed in Fuzzy Logic Toolbox fuzzy inference system (fuzzy air task efficiency evaluator) is presented in Fig. 5 and called "pochylenieprzechylenie" (in Polish language) "pitchroll" (in English language). The system is also no adaptive Mamdani - Zadeh MISO fuzzy system (Many Inputs, Single Outputs). There are two input signals: aircraft pitch angle and aircraft roll angle, and one output signal: efficiency number 2 . The ranges and parameters of membership functions and also fuzzy rules were determined from aircraft pilots' experience and technical documentation as was explained. $[10 \div 13]$ The evaluation results depend on the input parameters of the system.

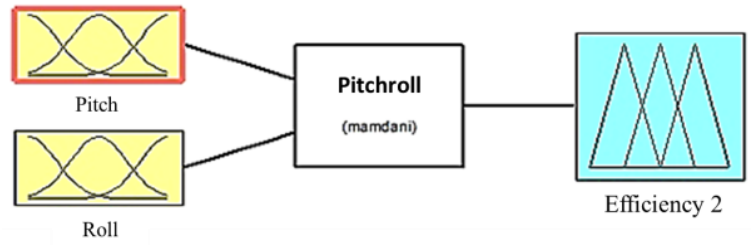

Figure 5: Fuzzy logic evaluator number 2 (Efficiency 2).

Fuzzy logic system efficiency evaluator is presented in Fig. 6.

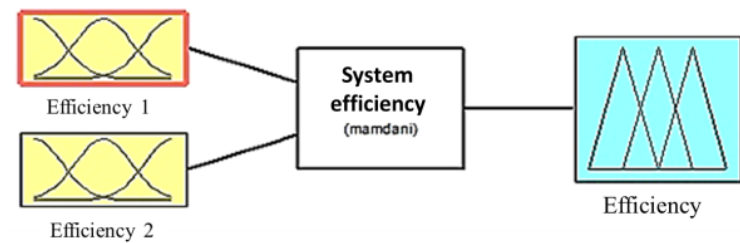

Figure 6: Fuzzy logic efficiency evaluator (calculated efficiency of the selected aircraft system from Efficiency 1 and 2).

The use of three separated fuzzy evaluators instead of one is intentional. It decreased the number of fuzzy rules $(25$ in the evaluator number 1,28 rules in the evaluator number 2 and 25 in the last one calculating efficiency of the system) and allows obtaining the calculation results in real time. If we used only one evaluator, the number of inference rules would be:

\section{$5 \cdot 5 \cdot 4 \cdot 7=700$.}

The centre of gravity method was used in all fuzzy evaluators during the defuzzification process. 


$$
y_{c}=\frac{\int_{y} \mu(y) y d y}{\int_{y} \mu(y) d y}
$$

or in discrete:

$$
y_{c}=\frac{\sum_{i} \mu\left(y_{i}\right) y_{i}}{\sum_{i} \mu\left(y_{i}\right)}
$$

\section{B. Project in Simulink Software}

The project in Simulink software is based on three Fuzzy evaluators (designed in Fuzzy Logic Toolbox, red colour in Fig. 7). Simulink Library was the source of the each block.

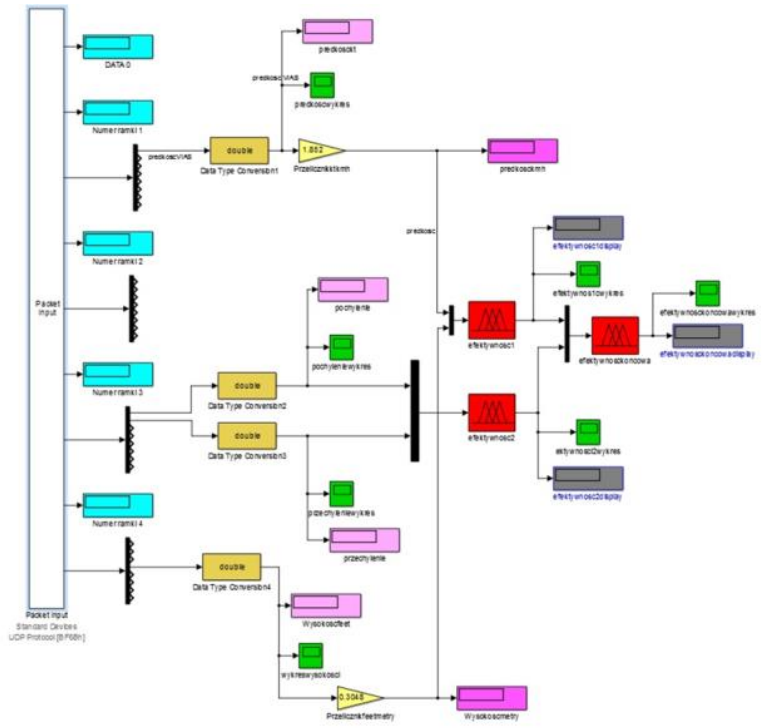

Figure 7: Fuzzy logic efficiency evaluator (designed in Simulink software).

First, the laboratory station computers were connected with an Ethernet cable. Then, after proper computers operating systems connection, the input data were imported to Matlab/Simulink software via LAN network with use of UDP protocol (User Datagram Protocol) and after adjusting to fuzzy evaluators.

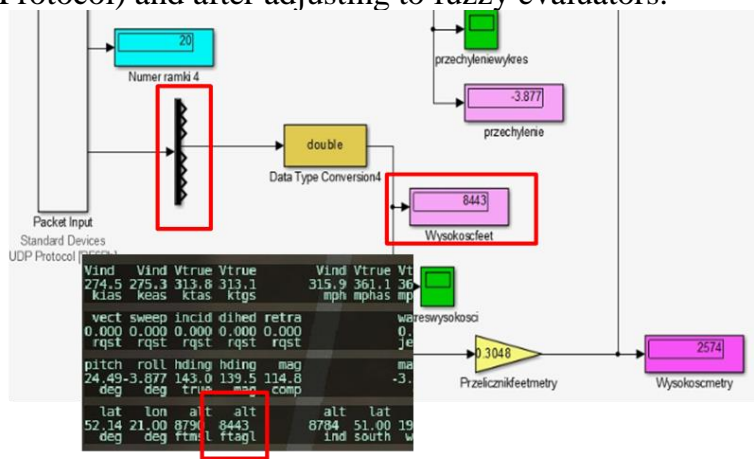

Figure 8: Fuzzy logic efficiency evaluator ("Altitude" input signal in X-Plane and fuzzy system, scaled in $\mathrm{ft})$.

\section{Research results}

\section{A. Results number 1}

Obtained data:

- aircraft velocity: $767.1[\mathrm{~km} / \mathrm{h}]$ (after conversion from $[\mathrm{kts}]$ );

- aircraft altitude: 378.6 [m] (after conversion from $[\mathrm{ft}])$;

- aircraft pitch angle: $-25.2\left[^{\circ}\right]$;

- aircraft roll angle: $55.22\left[^{\circ}\right]$;

- efficiency 1 (centre of gravity method in defuzzification process): 58.09 [\%];

- efficiency 2 (centre of gravity method in defuzzification process): $7.32[\%]$

- calculated system efficiency (centre of gravity method in defuzzification process): 21.05 [\%].

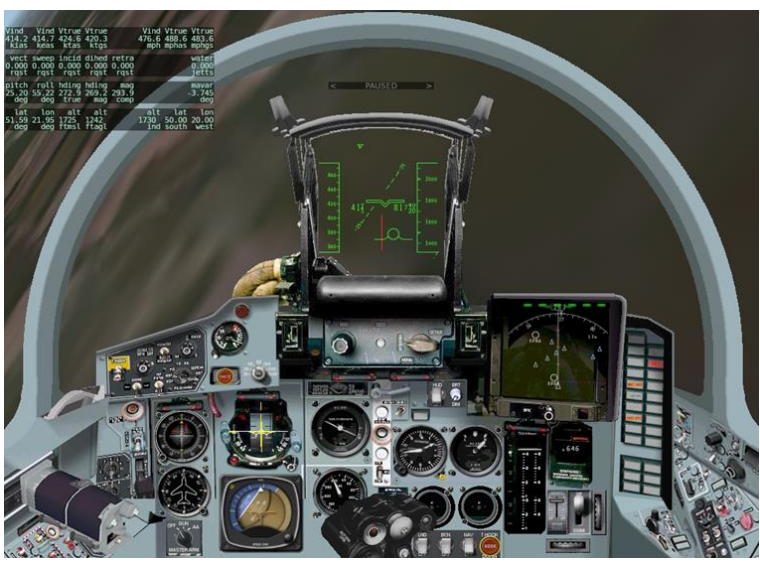

Figure 9: Cockpit view (during air task).

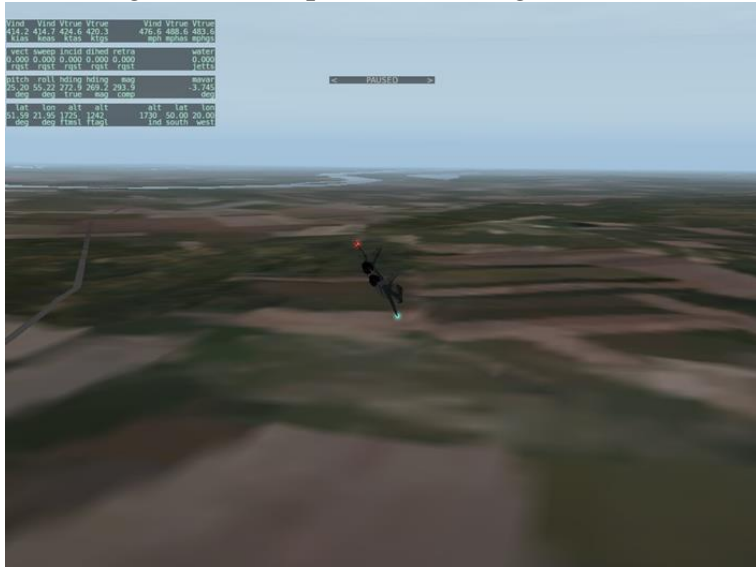

Figure 10: Location of the aircraft in the air.

The control surfaces of the designed efficiency evaluators are presented in Fig. 11. The first surface from the left presents efficiency number 1 and aircraft velocity and altitude dependency. The centre surface presents efficiency number 2 and aircraft pitch and roll angle dependency. The last one (first from the right) presents efficiency number 1 and 
efficiency number 2 and calculated system efficiency dependency.

The red marks on the control surfaces describe calculated output signals for selected input data.

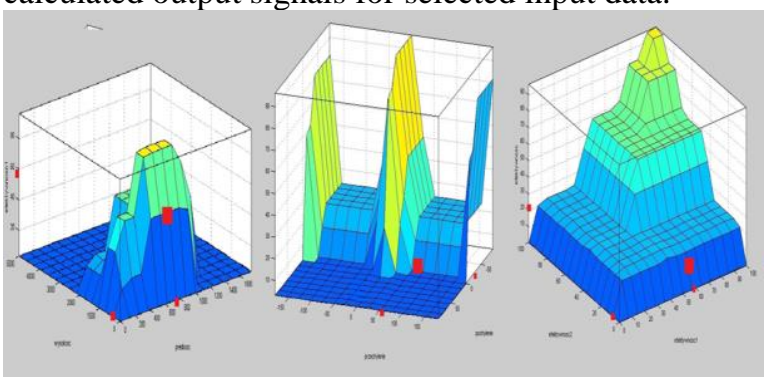

Figure 11: Control surfaces of the calculated

efficiencies (from the left: efficiency number 1 , efficiency number 2 and calculated efficiency of the selected aircraft system), red marks represents obtain data of results number 1 .

The calculated system efficiency is 21 [\%]. The optimal aircraft velocity during the particular air task is $767.1[\mathrm{~km} / \mathrm{h}]$, however aircraft altitude below 400 [m] AGL is too low to complete the task with higher efficiency. That is why efficiency 1 is almost 60 [\%]. Another undesirable factor is $55\left[^{\circ}\right]$ aircraft roll angle which also decreasing the calculated system efficiency. Comparing the received efficiency results to knowledge of experienced pilots and technical documentation data we can confirm the proper work of the designed system.

\section{B. Results number 2}

Obtained data:

- aircraft velocity: $753.6[\mathrm{~km} / \mathrm{h}]$ (after conversion from [kts]);

- aircraft altitude: 1117 [m] (after conversion from $[\mathrm{ft}])$;

- aircraft pitch angle: $-54.48\left[^{\circ}\right]$;

- aircraft roll angle: $5.509\left[^{\circ}\right]$;

- efficiency 1 (centre of gravity method in defuzzification process): 96.33 [\%];

- efficiency 2 (centre of gravity method in defuzzification process): 96.25 [\%];

- calculated system efficiency (centre of gravity method in defuzzification process): 95.98 [\%].

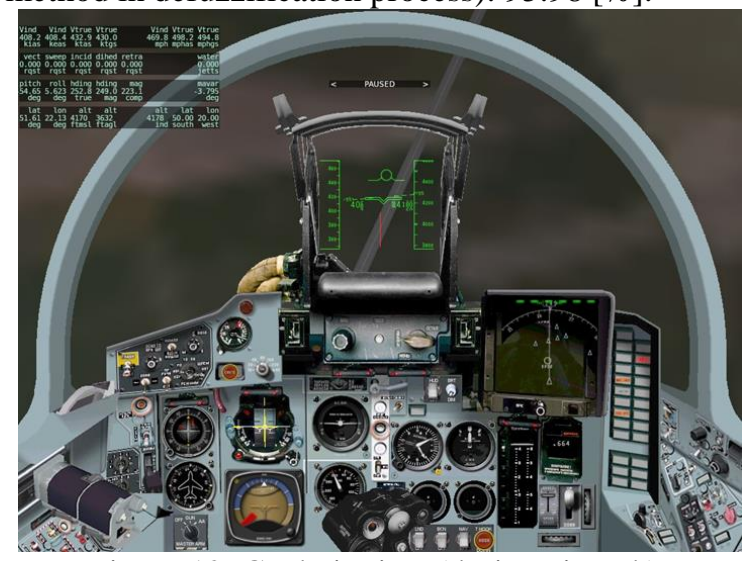

Figure 12: Cockpit view (during air task).

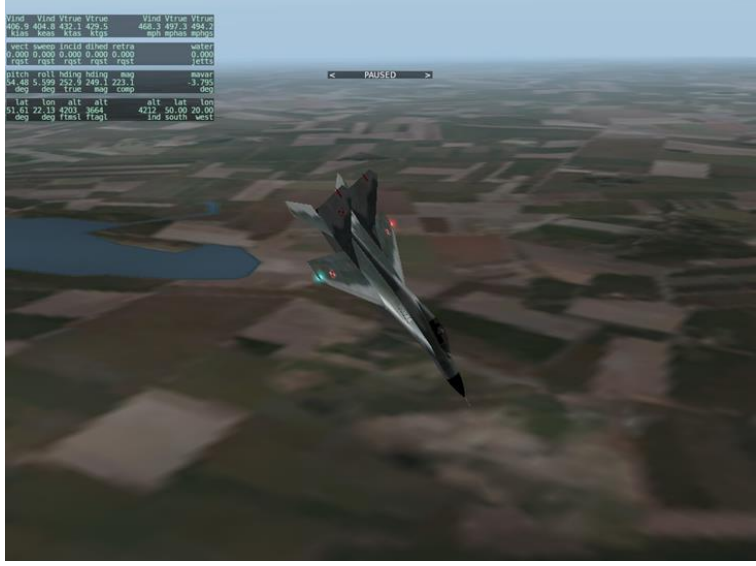

Figure 13: Location of the aircraft in the air.

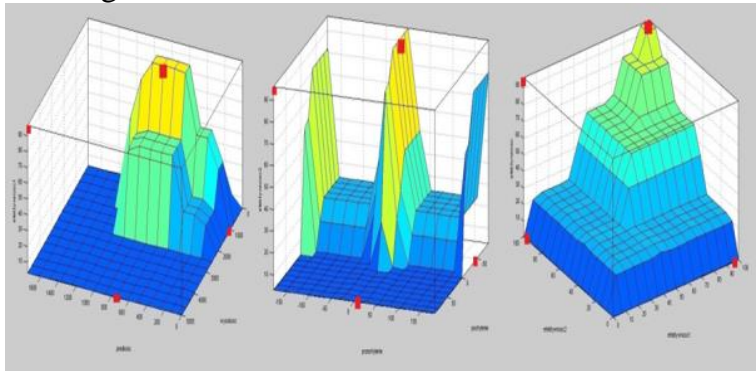

Figure 14: Control surfaces of the calculated efficiencies (from the left: efficiency number 1, efficiency number 2 and calculated efficiency of the selected aircraft system), red marks represents obtain data of results number 2 .

The calculated system efficiency is approximately 95 [\%]. All air task flight parameters are optimal. Usually the pilots do not execute that kind of air task with aircraft pitch angles above $40\left[^{\circ}\right]$, however in this particular example the calculated system efficiency will be as high as during the mission with aircraft pitch angles equal $40\left[^{\circ}\right]$. That is why efficiency 1 and 2 are very high. By comparing the received efficiency results with the knowledge of experienced pilots and technical documentation data, we can confirm a proper operation of the designed system.

\section{Results number 3}

Obtained data:

- aircraft velocity: 538 [km/h] (after conversion from [kts]);

- aircraft altitude: 1359 [m] (after conversion from

$[\mathrm{ft}]$ );

- aircraft pitch angle: $42.52\left[^{\circ}\right]$;

- aircraft roll angle: $-12.43\left[^{\circ}\right]$;

- efficiency 1 (centre of gravity method in

defuzzification process): 67.5 [\%];

- efficiency 2 (centre of gravity method in defuzzification process): 3.255 [\%];

- calculated system efficiency (centre of gravity method in defuzzification process): 1 [\%]. 


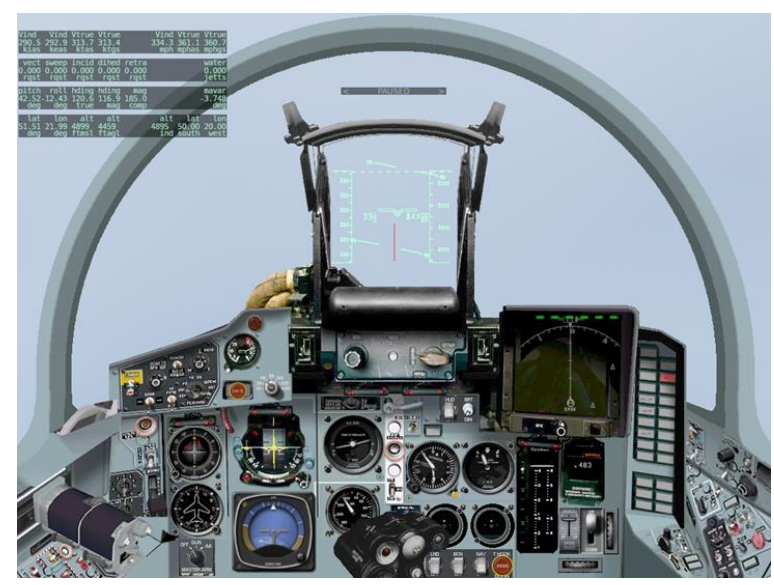

Figure 15: Cockpit view (during air task).

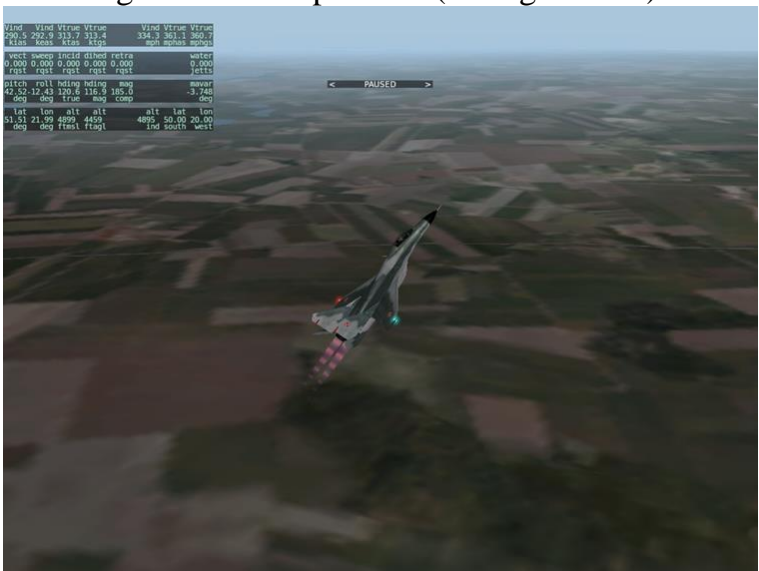

Figure 16: Location of the aircraft in the air.

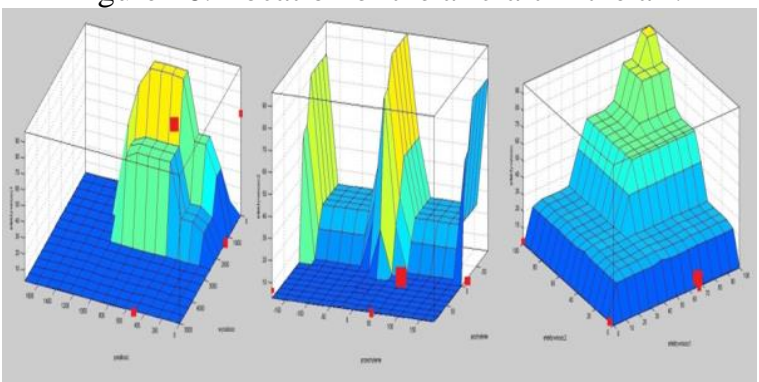

Figure 17: Control surfaces of the calculated efficiencies (from the left: efficiency number 1 , efficiency number 2 and calculated efficiency of the selected aircraft system), red marks represents obtain data of results number 3 .

The calculated system efficiency is approximately 1 [\%]. This very low level of system efficiency is due to an increase in aircraft altitude. That kind of system work is intentional, because if pilot chooses the long distance target and uses the gun system to neutralize it, there is a possibility of a success of that mission (but probability of success is very low - lower than $1[\%])$. By comparing the received efficiency results with knowledge of experienced pilots and technical documentation data, we can confirm the proper work of the designed system.

\section{Conclusion}

In the last decade a huge increase in machine designs and devices using fuzzy control systems is visible. This issue affects a very wide range of fields of science and technology. The attractiveness of fuzzy modelling results lies in its affordability, transparent mathematical and high efficiency of obtained models. The manuscript presents the practical implementation of modern engineering solutions in the field of fuzzy logic. The project of laboratory station evaluates the effectiveness of the Mig-29 aircraft selected air task using a gun system. According to the received results there is a possibility to use fuzzy logic in selected aircraft systems. In the future it could be an integral part of the aircraft on-board stores management systems. It will help a pilot to choose the optimal moment to use the system and complete the task with the highest efficiency. The laboratory station is one of the few that kind of solutions in Poland and only one solving described above problems.

The designed system is characterized by a fast and reliable operation. The inputs and output parameters vary smoothly with frequency of $99 \mathrm{~Hz}$. Its reliability and stability confirms that the efficiency of selected system is calculated in real time during the flight which is simulated by X-plane software.

The main benefits of fuzzy logic use in air task efficiency evaluation are:

- cost of air task (use of cheaper weapon to achieve a goal);

- system designing process is easier (Matlab Toolbox user interface) than classical, mathematical approach;

- air task efficiency evaluation is faster.

Next steps of the future research will be checking the membership functions shapes and defuzzification methods change and its influence to the results. Generally speaking it will helps to choose the best designing solutions to this particular problem. After that authors will try to develop the evaluation system with use of Takagi-Sugeno type model.

\section{Acknowledgement}

The project was implemented in cooperation with the Polish Air Force University, Aviation Faculty and University of Rzeszow, Mechanical Engineering and Aeronautics Faculty.

\section{References}

[1] G. Jaromi, Algorytmy sterowania rozmytego sterownikiem PLC, Politechnika Rzeszowska, Rzeszów 2004.

[2] A. Piegat, „Modelowanie i sterowanie rozmyte”. EXIT, Warszawa 1999. 
[3] N. Grzesik, Podstawy sterowania rozmytego. Projektowanie rozmytych systemów eksperckich w środowisku Matlab - Simulink, WSOSP, Dęblin 2012.

[4] L. Zadeh, The concept of linguistic variable and its applications to approximate reasoning. Part 13. Information Sciences, 1975.

[5] J. Kwaśniewski, Programowalne sterowniki przemysłowe w systemach sterowania, Kraków 1999.

[6] E. Czogała, W. Pedrycz, Elementy i metody teorii zbiorów rozmytych, PWN, Warszawa 1985.

[7] R. Yager, D. Filev, Podstawy modelowania i sterowania rozmytego, Wydawnictwo NaukowoTechniczne Warszawa 1995.

[8] L. Zadeh, Fuzzy Sets. Information and Control, 1965.

[9] H. Tomaszek, W. Wróblewski, Podstawy oceny efektywności eksploatacji systemów uzbrojenia lotniczego, Wydawnictwo Bellona, Warszawa 2001.

[10] Samolot MiG-29 - Instrukcja techniki pilotowania. WLOP 176/94, Poznań 1995.

[11] Samolot Mig-29 Metodyka szkolenia cz. II Zastosowanie bojowe. WLOP 28/90, Poznań 1991.

[12] Samolot Mig-29, Książka 2, Uzbrojenie cz.1. WLOP 9/90, Poznań 1991.

[13] M. Adamski, Rozwiązania konstrukcyjne uzbrojenia lotniczego, WSOSP, Dęblin 2007.

[14] N. Grzesik, Wykorzystanie sterowników rozmytych w badaniu efektywności systemów sterowania bronią strzelecką samolotów wielozadaniowych., WSOSP, Dęblin 2004.

[15] B. Mrozek, Z. Mrozek, Matlab. Wprowadzenie do oprogramowania Wydawnictwo Ago, Kraków 1994 r.

[16] The Math Works Inc., Fuzzy Logic Toolbox For Use with Matlab User's Guide, 1995-1998.

[17] A. Azadeh, V. Ebrahimipour, P. Bavar, A fuzzy inference system for pump failure diagnosis to improve maintenance process: The case of a petrochemical industry. Expert Systems with Applications 37 (2010) 627-639.
[18] Z. Idziaszek, N. Grzesik, Object characteristics deterio-ration effect on task realizability outline method of estima-tion and prognosis. Eksploatacja i Niezawodnosc - Maintennance and Reliability Vol.16, No. 3, 2014.

[19] M. Jasztal, J. Żurek, H. Tomaszek, A method of evaluating fatigue life of some selected structural components at a given spectrum of loads - an outline. Eksploatacja i Niezawodnosc, $\mathrm{Nr}$ 3(35)/2007, str.69-71.

[20] G.F. Mauer, A fuzzy logic controller for an ABS braking system. Fuzzy Systems, IEEE Transactions on Fuzzy Systems (Volume:3, Issue: 4), Page(s): 381 - 388, ISSN: 1063-6706.

[21] A. Sergaki, K. Kalaitzakis, A fuzzy knowledge based method for maintenance planning in a power system. Reliability Engineering and System Safety, 77 (2002) 19-30.

[22] H. Tomaszek, M. Jasztal, M. Zieja, A simplified method to assess fatigue life of selected structural components of an aircraft for a variable load spectrum. Eksploatacja i Niezawodnosc - Maintenance and Reliability; 4: 29-34, 2011

[23] R. R.. Yager, Uncertainty modeling and decision suport, Reliability Engineering \& System Safety, Volume 85, Issues 1-3, July-September: Pages 341-354, 2004

[24] J. Żurek, N. Grzesik, Fuzzy expert aircraft onboard control systems assistant. Safety reliability and risk analysis: Beyond the horizon. ESREL conference proceedings. London: Taylor \& Francis Group: Pages 250-251, 2014.

[25] L. Doitsidis, K.P. Valavanis, N.C. Tsourveloudis, M. Kontitsis, A framework for fuzzy logic based UAV navigation and control. Robotics and Automation, 2004. Proceed-ings. ICRA '04. 2004 IEEE International Conference on (Volume:4 ).

[26] J. H. Lemelson, R. D. Pedersen, T. D. Blake, Fuzzy logic based emergency flight control with thrust vectoring. US 6259976 B1. Patent.

[27] J. Luo, E. Lan, Fuzzy Logic Controllers for Aircraft Flight Control. Fuzzy Logic and Intelligent Systems International Series in Intelligent Technologies Volume 3, 1995, pp 85124.

[28] Kacprzyk J., Wieloetapowe sterowanie rozmyte. WNT. Warszawa 2001. 
[29] Kacprzyk J., Zbiory rozmyte w analizie systemowej. PWN. Warszawa 1986.

[30] K. Narenathreyas, Fuzzy Logic Control for Aircraft Longitudinal Motion. Master Thesis, Czech Technical University Department of Control Engineering Faculty of Electrical Engineering, Prague, 2013.

[31] T. Kowalewski, A. Podsiadło, W. Tarełko, Application of fuzzy inference to as-sessment of degree of hazard to ship power plant operator. Polish Maritime Research, 2007, nr 3, pp 7-11.

[32] K. Nho, R. K. Agarwal, Automatic Landing System Design Using Fuzzy Logic. Journal of Guidance, Control, and Dynamics, Vol. 23, No. 2 (2000), pp. 298-304.

[33] M. Ali Usta, ÖmürAkyazı and SefaAkpınar, Aircraft Roll Control System Using LQR and Fuzzy Logic Controller. 2011, IEEE,978-161284-922-5/11/26.00.

[34] M. Hadjimichael, A fuzzy expert system for aviation risk assessment. Expert Systems with Applications Volume 36, Issue 3, Part 2, April 2009, Pages 6512-6519.

[35] N. Wahid, MohdFua'adRahmat, Pitch Control System Using LQR and Fuzzy Controller. 2010 IEEE Symposium on Industrial Electronics and Applications (ISIEA 2010), October 3-5, 2010, Penang, Malaysia (01.03.2011).

[36] Usta, M.A., Akyazi, O., Akpinar, A.S., Aircraft roll control system using LQR and fuzzy logic controller. Innovations in Intelligent Systems and Applications (INISTA), 2011.

[37] Vishnu G Nair, M. V. Dileep, K. R. Prahalad, Design of Fuzzy Logic Controller for Lateral Dynamics Control of Aircraft by Considering the Cross-Coupling Effect of Yaw and Roll on Each Other. International Journal of Computer Applications (0975 - 888) Volume 47- No.13, June 2012. 